Northwestern University School of Law Northwestern University School of Law Scholarly Commons

Faculty Working Papers

2011

\title{
The Global Spread of European Style International Courts
}

Karen J. Alter

Northwestern University School of Law, kalter@northwestern.edu

\section{Repository Citation}

Alter, Karen J., "The Global Spread of European Style International Courts" (2011). Faculty Working Papers. Paper 7. http://scholarlycommons.law.northwestern.edu/facultyworkingpapers/7 


\section{Buffett Center for International and Comparative Studies Working Paper Series}

\section{The Global Spread of European Style International Courts}

Karen J. Alter

Department of Political Science, Northwestern University

Working Paper No. II-003

June $201 \mathrm{I}$ 


\title{
The Global Spread of European Style International Courts
}

\author{
By Karen J. Alter, Northwestern University ${ }^{*}$ \\ Forthcoming in West European Politics
}

\begin{abstract}
:
Europe created the model of embedded international courts (IC), where domestic judges work with international judges to interpret and apply international legal rules that are also part of national legal orders. This model has now diffused around the world. This article documents the spread of European-style ICs: there are now eleven operational copies of the European Court of Justice (ECJ), three copies of the European Court of Human Rights, and a handful of additional ICs that use Europe's embedded approach to international law. After documenting the spread of European-style ICs, the article then explains how two regions chose European style ICs, yet varied from the ECJ model.
\end{abstract}

Key words: International Courts, European Court of Justice, legal integration, regionalism, African courts

Author's bio:

Karen J. Alter is Professor of Political Science at Northwestern University and author of The European Court's Political Power: Essays on the Influence of the European Court of Justice on European Politics (Oxford University Press, 2009) and Establishing the Supremacy of European Law: The Making of an International Rule of Law in Europe (Oxford University Press, 2001) and over thirty articles and book chapters on the politics of international courts and international law. Fluent in Italian, French and German, Alter's research has been supported by the John Simon Guggenheim Foundation, the American Academy of Berlin, the Howard Foundation, the German Marshall Fund, the DAAD, and the Bourse Chateaubriand Scientifique. Alter is currently working on a book titled The New Terrain of International Law: International Courts in International Politics that examines how delegation to international courts is transforming international relations.

This article is motivated by an observation-- the global spread of European style international courts (ICs). Up until the creation of the European Court of Justice and the European Court of Human Rights, international courts were primarily designed to adjudicate disputes between states when both parties desired. With consent required for litigation to proceed, governments could simply refuse to litigate cases where serious issues were at stake. The architects of the European Community and the European Human Rights systems, however, wanted meaningful international

Thanks to Tanja Börzel, Tobias Lenz, Diana Panke, Gustav Kalm, Thomas Risse, Cesare Romano and Osvaldo Saldias for comments on earlier versions of this paper, and to the Kolleg-Forschergruppe "The Transformative Power of Europe" for the inspiration and guidance to think more systematically about Europe's contribution to the spread of international courts. 
oversight of state behaviour. They added design features to make international oversight possible, including compulsory jurisdiction so that states could not block valid cases from proceeding and the right of nonstate actors to initiate litigation. These design features, and others, have been copied. There are now eleven operational copies of the European Court of Justice (ECJ) and three adaptations of the European Court of Human Rights (ECtHR). The larger claim of this article, however, is that Europe's most important legal export is not so much its formal legal institutions, but rather the embedded approach to making international law effective. European-style ICs exist where international legal rules are part of national legal orders, and where national and international judges mutually converse about the application of these rules in concrete cases. Because supra and sub-national actors are applying the same or similar law to concrete cases, European style ICs are generally perceived to be better able to work with domestic lawyers, administrative actors and judges to facilitate the domestic application of international law than are inter-state courts.

The article begins with the creation of the innovative yet largely unused ECtHR and ECJ. I return to this history to show that despite their revolutionary designs, neither court was particularly active or effective in their early years. I briefly describe how Europe created its system of embedded international law through practice. Focusing on emulation of the ECJ model, I show how regional integration systems in Latin American and Africa have emulated the ECJ while adapting certain features to protect national sovereignty. I then examine comparative litigation data, which suggests that most ECJ emulators are at this point similar to the early ECJ; a dearth of secondary legislation combines with limited support from national judges to inhibit litigation.

We lack detailed histories about the creation of most ICs, which makes explaining ECJ emulation difficult. I briefly report on the findings of my research on the Community Courts for the Organization for the Harmonisation of Business Law in Africa and the Economic Community of West African States. In these and other cases I have studied, policy-makers were drawing lessons from Europe while adapting the ECJ model to accommodate state concerns and to fit the particular needs of regional actors.

The conclusion argues that the existence of ECJ copies means that we can now hold constant the design of a court to investigate what makes different international courts more and less active and effective. But if the argument of this paper is correct, we should not focus too 
much on the fact of institutional copying. We should instead investigate the conditions that lead national lawyers, administrators and judges to be willing to work with international judges to apply international legal rules in the national legal order.

\section{Creating European-Style ICs Through Practice}

The ECJ and the ECtHR were from inception unusual in that they both included compulsory international oversight of state actions (Levi 1976: 70-1). The motivation that led to the ECJ and ECtHR's unique designs in itself created permissive conditions allowing for the ECtHR and ECJ systems to be transformed through practice. The Nazi empire and World War II made Europeans suspicious about unfettered German power and about powerful political institutions - even democratic institutions - lacking meaningful legal and political checks. Created in the 1950s, Europe's supranational legal systems were intended as partial remedies for unchecked power.

The European Human Rights system was meant to be a supranational check on state respect for human rights (Madsen et al. 2005). In contrast to the nonbinding United Nations Universal Declaration of Human Rights, the European Convention on Human Rights (adopted in 1950) was legally binding. Also different was that in ratifying the European Convention, every member of the Council of Europe agreed to allow a European Commission on Human Rights to investigate complaints about human rights violations. A number of countries feared, however, that a highly independent international oversight mechanism would compromise national sovereignty and that "the supremacy of national courts would be degraded if an international organ would be permitted to criticize their judicial decisions" (Schermers 1999: 822). Thus the Commission's formal mandate prioritized friendly reconciliation over enforcement actions (Robertson et al. 1994: 5-12, 295-296). Also, consent to the authority of the ECtHR and to the right of individual appeals to the European Commission on Human Rights were made optional, with states allowed to opt in for a few years at a time. For the first two decades of its existence, key European states refused to accept the Court's compulsory authority and even those that accepted the Court's authority at times threatened to withdraw their support (Bates 2011: 238283).

Europe's other approach to international law enforcement was its Coal and Steel Community (ECSC). The ECSC was meant to ensure that Germany did not use its market 
dominance in coal and steel to favour German reconstruction over reconstruction in other countries (Gillingham 1991). The ECJ, created in 1952 as part of the ECSC, was designed to provide a legal check on the ECSC High Authority (Boerger-De Smedt 2008). The ECJ had compulsory jurisdiction and private access so that individuals could challenge arguably illegal High Authority actions. The ECSC system also had a novel preliminary ruling mechanism that allowed national judges to send legal questions to the ECJ so that the ECJ could help national judges interpret technical ECSC rules (Pescatore 1981). Member-states retained these basic design elements when ECSC institutions were adapted for the goal of the European Economic Community (EEC). While the newly christened EEC Commission lost its authority to rule itself on state or firm compliance with European rules, the ECJ remained the final arbiter of state compliance with Community rules. The ECJ's oversight authority was not optional, and in this respect the legal apparatus of the EEC reflected a greater self-binding commitment compared to the Council of Europe's human rights system. But the EEC legal system was not very muscular either. Non-compliance cases could result in the ECJ declaring that a member state had "failed to fulfil its obligations" under the Treaty of Rome. Such a declaration was largely toothless in that no remedies were associated with an ECJ finding of a violation of European law.

Despite their revolutionary designs, in the 1950s and 1960s both of Europe's supranational courts were barely used. Worried that too much law enforcement might keep European states from consenting to the ECtHR's authority, the European Commission on Human Rights limited to types of cases it referred to the ECtHR. Between 1954 and 1961, 1307 applications were filed with the Commission of which only 7 were declared admissible - a success rate of one half of one percent (Schermers 1999: 825). The ECJ heard more than seven cases, but according to Stuart Scheingold the role of the ECJ in the ECSC remained quite limited. Especially after the defeat of the European Defence Community Treaty in 1954, more disputes were resolved through out of court negotiation and the ECJ focused on procedural issues avoiding entering the political fray where possible (Scheingold 1965: 265-6). In the 1950s and early 1960s the ECJ developed precedents and facilitated procedural regularity, but it was unable to help stem violations of ECSC rules or to promote the actual creation of a common market in coal and steel (Alter 2009: chapter 3).

Graph 1 suggests that Europe's supranational courts took years to reach their potential. In their first years of operation, neither the ECJ (founded in 1953) nor the ECtHR (founded in 
1959) were very active. The larger question, however, is whether the legal regimes contributed to greater respect for legal rules they oversaw? While one can find doctrinally significant decisions, it is hard to find a substantively important ECJ or ECtHR ruling from the early period, which explains why few people considered Europe's supranational courts as very important in the 1960s or even the 1970s.

\section{Graph 1: Litigation Rates over time in the ECJ and ECtHR (Founding-2009)}

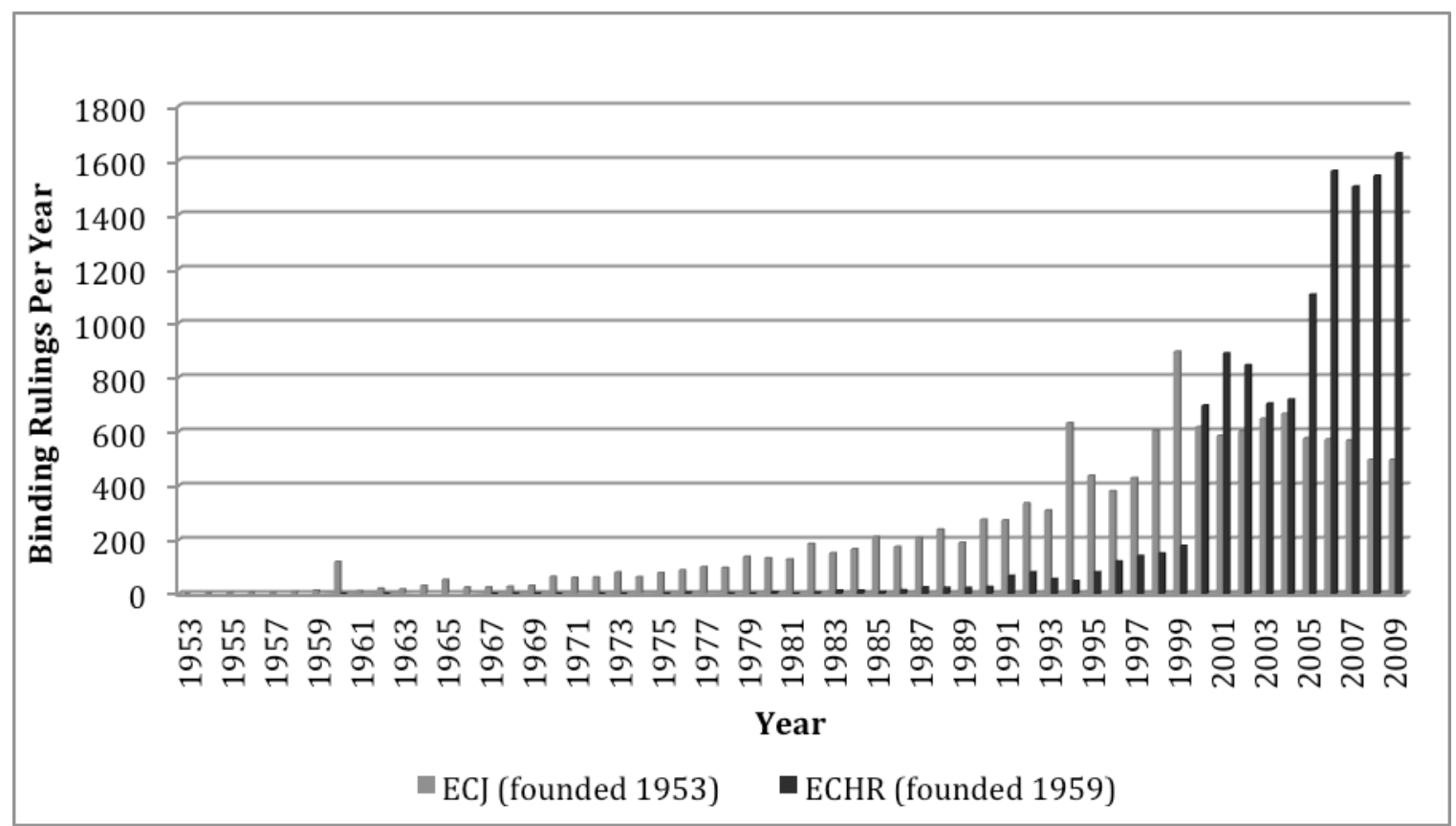

I repeat this early history for three reasons. First, this history reminds us that sovereignty concerns for many years affected the design and operation of Europe's supranational commissions and courts. Second, this history reminds us even for ICs operating in democratic contexts, with independent and robust domestic rule of law systems, where the norms the ICs were asked to enforce overlap significantly with the norms and values of national governments and domestic populations, drafting bold IC charters is not enough to make ICs independent and effective in practice. Third, this history is relevant today because most ECJ and ECtHR copies are operating in contexts that are very similar to Europe of the 1950s and 1960s. Scheingold (1965) saw the weakness of the ECSC High Authority and the lack of state commitment to the integration process as fundamental limits on the ECJ's ability to develop a rule of law. This is exactly the situation of ECJ copies in Africa and Latin America.

Litigants, lawyers and judges helped to transform Europe's supranational courts through 
practice. The ECJ's bold doctrines regarding the direct effect and the supremacy of European law, which authorized litigants to invoke European rules in front of national judges and made national judges co-enforcers of Community law, helped to build a constitutional federal legal order at a time when the political process of integration was largely paralyzed (Weiler 1991 ; Stein 1981). Litigation rates and the political import of ECJ rulings rose as European member states passed secondary implementing legislation to build a common market, giving litigants legal texts worth invoking, engaging national administrations and judges in enforcing European law, and giving the ECJ a platform upon which to build integration promoting jurisprudence (Stone Sweet 2004: 59). Changing attitudes also mattered. In the 1980s European governments once again embraced the goal of completing the Single Market, because market integration was seen as a way to help European industries build global competitiveness (Hanson 1998). In the human rights system, by "1993 there was no longer a reasonable risk that member states would not renew the right of individual petition or that they would withdraw from the Convention. Public opinion in the member states and the Council of Europe would not easily accept such a step" (Schermers 1999: 825). Through living with active and engaged supranational courts, Europeans grew to accept, if not always appreciate, the contributions of the ECJ and ECtHR to European politics. In the 1980s and 1990s member states embraced the court's legal revolutions, adopting institutional reforms aimed at reinforcing the existing systems. The European Community added a Tribunal of First Instance and system of sanctions to use against states that ignored ECJ rulings. The Council of Europe gave private actors direct access to the ECtHR, making the right of individual appeal and ECtHR jurisdiction compulsory for all Council of Europe members.

The slow transformation of Europe's supranational legal mechanisms showed the world that combining domestic enforcement with international legal oversight contributes to making international law more effective (Helfer et al. 1997 ; Hathaway 2005). Europe also showed the world that robust international legal oversight can co-exist with important national values such as democracy, dealing with security threats, and respecting heterogeneous national values.

\section{Spreading European Style Courts through Institutional Emulation}

This section documents emulation of the EU's legal institution. The fact of legal emulation is not surprising. When faced with an institutional problem, lawyers typically look 
around the world for examples of how other legal systems have dealt with the issue. The result is a remarkable similarity in the formal structure of law and legal systems (Watson 1993). The earliest emulations of the ECJ were by the Benelux countries (1974) and the Andean Pact (1984). Both the Benelux and Andean decisions to emulate the EEC legal system makes sense when one considers that the alternative of the time was the GATT dispute resolution system, which in the 1970s was pretty much defunct. ${ }^{1}$ By the 1990s, institutional emulators had a larger choice set. They could emulate the ECJ or the compulsory dispute settlement system of the World Trade Organization (WTO), or create their own amalgam. Since most members of regional integration systems are current or aspiring members of the WTO, the WTO's compulsory system is for many countries a default system for resolving trade disputes.

The GATT/WTO system has compulsory jurisdiction and the right for states to initiate non-compliance suits against other states. Four international economic systems emulate the WTO dispute resolution system - the North American Free Trade Area (created 1992), Economic Community of the Commonwealth of Independent States (created 1992), Southern Common Market (Mercosur, created 2004) and the Association of Southeast Asian Nations (ASEAN) Dispute Resolution Mechanism (created 2004). The ECJ model adds 1) a supranational Commission that monitors state compliance and brings non-compliance cases to the supranational court; 2) a preliminary ruling mechanism that allows national courts to send references to the supranational court; 3) systems of administrative and constitutional review that allow states, community institutions and private litigants to challenge community acts in front of the supranational court. Table 1 identifies eleven operational ICs that copy at least two features of the ECJ model. This list of operating ECJ emulators is conservative. There are also two proposed ECJ-style African courts ${ }^{2}$ and proposals to convert the Economic Court for the Commonwealth of Independent States and the Mercosur system into ECJ style legal systems. There are also three emulations of the European human rights system, which is pretty much the only model of an international human rights court to choose from. ${ }^{3}$ And there are ICs that do not

\footnotetext{
${ }^{1}$ The GATT system required state parties to consent for a case to proceed and before any panel finding would be made binding, and in the 1970s Europe and the United States were blocking most cases from proceeding (Hudec 1993: 29-42). ${ }^{2}$ The proposed African Court of Justice may allow a supranational commission to initiate enforcement actions, and it may have administrative and constitutional review authority. The draft charter of the Court of Justice of the Economic Community of Central African States allows Conference of Heads of State to initiate noncompliance suits, and it envisions preliminary rulings and administrative and constitutional review cases.

${ }^{3}$ The Inter-American Court of Human Rights (created in 1979) and African Court of Peoples and Human Rights (created in 2006) emulate the original ECtHR, where a Commission investigates complaints and serves as a gate-keeper to the
} 
directly copy the ECJ or ECtHR models, but intentionally embed international law into domestic legal orders, such as the OHADA system discussed later. One could also see the International Criminal Court (ICC) system as using an embedded approach where countries are supposed to adopt national war crimes statutes so that either domestic judges or the ICC can prosecute war criminals.

Table 1: ECJ Copies (ordered by the year the court was established)

\begin{tabular}{|c|c|c|c|c|}
\hline International Court & $\begin{array}{c}\text { Supranational } \\
\text { Commission can raise } \\
\text { non-compliance suits }\end{array}$ & $\begin{array}{l}\text { Preliminary ruling } \\
\text { system of national } \\
\text { court referrals }\end{array}$ & $\begin{array}{c}\text { Explicit } \\
\text { administrative } \\
\text { review authority }\end{array}$ & $\begin{array}{c}\text { Explicit } \\
\text { constitutional } \\
\text { review authority }\end{array}$ \\
\hline ECJ (1952) & $\mathrm{X}$ & $\mathrm{X}$ & $\mathrm{X}$ & $\mathrm{X}$ \\
\hline Benelux court (BCJ) (1974) & & $\mathrm{X}$ & $\mathrm{X}$ & $\mathrm{X}$ \\
\hline $\begin{array}{l}\text { Andean Tribunal of Justice } \\
\text { (ATJ) (1984) }\end{array}$ & $\mathrm{X}$ & $\mathrm{X}$ & $\mathrm{X}$ & $\mathrm{X}$ \\
\hline $\begin{array}{l}\text { Central American Court of } \\
\text { Justice (CACJ) (1992) }\end{array}$ & & $\mathrm{X}$ & $\mathrm{X}$ & $\mathrm{X}$ \\
\hline $\begin{array}{l}\text { European Free Trade Area } \\
\text { Court (EFTAC) (1994) }\end{array}$ & $\mathrm{X}$ & $\begin{array}{c}\text { Advisory } \\
\text { Opinions Only }\end{array}$ & $\mathrm{X}$ & \\
\hline $\begin{array}{l}\text { West African Economic and } \\
\text { Monetary Union (WAEMU) } \\
\text { (1995) }\end{array}$ & $\mathrm{X}$ & $\mathrm{X}$ & $\mathrm{X}$ & $\mathrm{X}$ \\
\hline $\begin{array}{l}\text { Common Market for East } \\
\text { African States (COMESA) (1998) }\end{array}$ & $\mathrm{X}$ & $\mathrm{X}$ & $\mathrm{X}$ & $\mathrm{X}$ \\
\hline $\begin{array}{l}\text { Central African Monetary } \\
\text { Community (CEMAC)(1999) }\end{array}$ & $\mathrm{X}$ & $\mathrm{X}$ & $\mathrm{X}$ & $\mathrm{X}$ \\
\hline $\begin{array}{l}\text { East African Community Court } \\
(\text { EACJ) }(2001)\end{array}$ & $\mathrm{X}$ & $\mathrm{X}$ & $\mathrm{X}$ & $\mathrm{X}$ \\
\hline $\begin{array}{l}\text { Caribbean Court of Justice } \\
(\mathrm{CCJ})(2004)\end{array}$ & $\begin{array}{l}\text { Currently under } \\
\text { discussion }\end{array}$ & & $\mathrm{X}$ & $\mathrm{X}$ \\
\hline $\begin{array}{l}\text { Court of Justice of the Economic } \\
\text { Community of West African } \\
\text { States (ECOWAS) (2002) }\end{array}$ & $\mathrm{X}$ & & $\mathrm{X}$ & $\mathrm{X}$ \\
\hline $\begin{array}{l}\text { Southern African Development } \\
\text { Community (SADC) (2007) }\end{array}$ & $\mathrm{X}$ & $\mathrm{X}$ & & $\mathrm{X}$ \\
\hline $\begin{array}{l}\text { Total ICs with this feature } \\
\text { (including ECJ) }\end{array}$ & 9 & 10 & 11 & 10 \\
\hline
\end{tabular}

ECJ copies were created after the ECJ's legal revolution, with twenty-twenty hindsight. Table 2 identifies key differences in the design of the ECJ copies, focusing on the preliminary ruling mechanism and the non-compliance procedure.Even though the Benelux Court (created in 1974) copied a fairly inactive ECJ, the creators of the Benelux Court nonetheless felt the need to state that the court could only respond to questions posed to it. Starting in the 1980s, emulators

court. The ECOWAS system (created in 2005) emulates today's version of the ECtHR where private parties can appeal cases directly to the court. 
had an even better sense of the activism of the ECJ. Some of the emulators wrote into their court's founding treaties provisions designed to limit judicial activism. For example a number of ECJ copies make national court references optional. ${ }^{4}$ Others require the consent of supranational political bodies before non-compliance cases can proceed to the court. Some emulators, however, have designs that are in theory even more politically intrusive than the ECJ. For example, the COMESA system explicitly allows its IC to review the validity of community and national acts and the SADC, CEMAC and ATJ systems allow private actors to bring disputes with states directly to the court. Some ECJ copies explicitly incorporate the direct effect and supremacy of community law, and include requirements for national judges to respect the rulings of the community court; others come with this understanding attached. There are some variations in the system of remedies, but the embedded law approach tends to rely on national court enforcement rather than sanctions to induce compliance.

\footnotetext{
${ }^{4}$ It is not clear that an 'obligation' to refer cases makes much of a difference either way, as national judges are able to generate reasons not to refer cases.
} 
Table 2: Design variations in translating ECJ Model (ordered by year the court was created)

\begin{tabular}{|c|c|c|}
\hline IC & Preliminary Ruling Mechanism & Noncompliance procedure and remedies for noncompliance \\
\hline Benelux Court (1974) & $\begin{array}{l}\text { Same as the ECJ, but the Benelux court can only respond } \\
\text { to the question posed to it. }\end{array}$ & $\begin{array}{l}\text { Not applicable in part because all Benelux states were in the European } \\
\text { Economic Community, but there may be state liabilities for state errors that } \\
\text { harm individuals. }\end{array}$ \\
\hline $\begin{array}{l}\text { Central American } \\
\text { Court of Justice } \\
(\text { CACJ })(1992)^{8}\end{array}$ & $\begin{array}{l}\text { The court can hear preliminary ruling references, but } \\
\text { national judges are not obliged to refer cases. }\end{array}$ & $\begin{array}{l}\text { The Court can hear noncompliance cases, including cases raised by affected } \\
\text { private litigants, but there is no supranational body monitoring state } \\
\text { compliance. No remedies specified. }\end{array}$ \\
\hline $\begin{array}{l}\text { West African } \\
\text { Economic and } \\
\text { Monetary Union }\end{array}$ & $\begin{array}{l}\text { Same as ECJ. Court rulings are explicitly made binding } \\
\text { on national judges and administrators and the } \\
\text { Commission can seize the Court if it suspects that a }\end{array}$ & $\begin{array}{l}\text { Noncompliance procedure is the same as the ECJ. Political bodies may } \\
\text { agree to additional unspecified sanctions for ongoing noncompliance. }\end{array}$ \\
\hline
\end{tabular}

\footnotetext{
${ }^{5}$ Articles 234, 228 and 229 of the Consolidated Treaty Establishing the European Community Treaty establishing the European Community (Official Journal C 325 of 24 December 2002.) The ECJ's Francovich Doctrine created state liabilities for damages due to national non-implementation of European law (see: Andrea Francovich and Others v. Italian Republic, Joined Cases C-6/90 and C-9/90 and C-9/90, [1991] ECR I-5357.)

${ }^{6}$ Article 6 of the Treaty Establishing the Benelux Court, March 31, 1965; modified via protocols June 10, 1981 and November 23 1984. The Treaty Establishing the Benelux Economic Union 381 U.N.T.S. 165 (1960).

${ }^{7}$ Article 34, 23-25 and 27 of Treaty Creating the Court of Justice of the Cartagena Agreement (Amended by the Cochabamba Protocol).

http://www.comunidadandina.org/INGLES/normativa/ande trie2.htm. For more on how the Andean system changed over time see: (Alter et al. 2011c)

${ }^{8}$ Article 22 (k) and (b) of the Statute of the Central American Court of Justice 34 I.L.M. 921 (1995). For more see: (Nyman Metcalf et al. 2005: 62)

${ }^{9}$ Agreement between the EFTA States on the Establishment of a Surveillance Authority and a Court of Justice. OJ L 344, 31.1.1994 Article 19 and 35. The

Surveillance authority is explicitly obligated to ensure that procurement rules, state aid rules and competition rules are respected (see Articles 22-26).

${ }^{10}$ Protocol 1 article 8, 13, 5 and 14 and Article 74 Treaty Establishing the West African Economic and Monetary Union and Additional Protocol No. 1 relative to the Organs of Control of WAEMU (UEMOA). Done in Dakar, Senegal on January 10, 1994 available at http://www.aict-
} 


\begin{tabular}{|c|c|c|}
\hline$\left(\right.$ WAEMU) $(1995)^{10}$ & national court has failed to refer a case. & \\
\hline $\begin{array}{l}\text { Common Market for } \\
\text { East African States } \\
(\text { COMESA) (1998) }\end{array}$ & $\begin{array}{l}\text { Same as ECJ except that references are only mandatory if } \\
\text { they are "deemed necessary." The treaty clearly states that } \\
\text { Community Court decisions have precedence over } \\
\text { national court decisions on similar matters. }\end{array}$ & $\begin{array}{l}\text { A Council of States must agree before legal violations are referred to the } \\
\text { Court. The Court may prescribe unspecified penalties it deems necessary } \\
\text { should parties not implement its ruling. }\end{array}$ \\
\hline $\begin{array}{l}\text { Central African } \\
\text { Monetary Community } \\
\left(\text { CEMAC) }(1999)^{12}\right.\end{array}$ & $\begin{array}{l}\text { Same as ECJ. The Treaty explicitly states that CEMAC } \\
\text { rulings are binding on national administrative authorities } \\
\text { and judges. }\end{array}$ & $\begin{array}{l}\text { Noncompliance procedure is the same as the ECJ. The treaty also allows any } \\
\text { organ of CEMAC and any person to raise a case alleging that a member } \\
\text { state has misinterpreted the treaty or subsequent conventions. A Council of } \\
\text { the Heads of States can be convened to authorize additional unspecified } \\
\text { sanctions for ongoing noncompliance. }\end{array}$ \\
\hline $\begin{array}{l}\text { East African } \\
\text { Community Court } \\
\left(\text { EACJ) }(2001)^{13}\right.\end{array}$ & $\begin{array}{l}\text { National courts only need refer to the EACJ cases where } \\
\text { it considers an answer to the question is necessary for it to } \\
\text { deliver a judgment. The treaty clearly states that EACJ } \\
\text { decisions have precedence over national court decisions } \\
\text { on similar matters. }\end{array}$ & $\begin{array}{l}\text { The Secretary General first refers noncompliance cases to a Council of } \\
\text { States. If the Council does not resolve the matter, they will direct the } \\
\text { General Secretary to refer the matter to the court. No remedies are specified. }\end{array}$ \\
\hline \begin{tabular}{|l|} 
Caribbean Court of \\
Justice (CCJ) $(2004){ }^{14}$
\end{tabular} & $\begin{array}{l}\text { National courts only need refer to the CCJ cases where it } \\
\text { considers that an answer to the question is necessary for it } \\
\text { to deliver a judgment. }\end{array}$ & $\begin{array}{l}\text { There is no noncompliance provision, although this system is new and } \\
\text { evolving. The CCJ can agree to let private actors raise cases, but subject to } \\
\text { conditions one of which is that member states declined to raise the suit } \\
\text { themselves. }\end{array}$ \\
\hline $\begin{array}{l}\text { Court of Justice of the } \\
\text { Economic Community } \\
\text { of West African States } \\
(\text { ECOWAS) (2002) }\end{array}$ & $\begin{array}{l}\text { The Court has jurisdiction over any national proceeding } \\
\text { referred to it, but there is no requirement that national } \\
\text { judges refer cases. }\end{array}$ & $\begin{array}{l}\text { Member states can bring noncompliance actions on behalf of their citizens. } \\
\text { The supplementary protocol of } 2005 \text { allows the Commission to also raise } \\
\text { noncompliance suits. The treaty allows the suspension of Community loans, } \\
\text { assistance, appointment to posts, and voting rights as a remedy for } \\
\text { noncompliance. As the case study discusses, the ECOWAS court can hear } \\
\text { private appeals regarding human rights violations. }\end{array}$ \\
\hline $\begin{array}{l}\text { Southern African } \\
\text { Development } \\
\text { Community (SADC) } \\
(2007)^{16}\end{array}$ & $\begin{array}{l}\text { The Court has jurisdiction over any national proceeding } \\
\text { referred to it, but there is no requirement that national } \\
\text { judges refer cases. }\end{array}$ & $\begin{array}{l}\text { There is no monitoring commission, but private actors can bring } \\
\text { noncompliance suits after domestic remedies are exhausted. SADC includes } \\
\text { a parallel inter-state dispute resolution system that is modeled on the WTO } \\
\text { system. }\end{array}$ \\
\hline
\end{tabular}

ctia.org/courts_subreg/waemu/waemu_docs.html

${ }_{11}$ Articles 29, 25.3, 30 and 34 of the Treaty Establishing the Common Market of Eastern and Southern Africa. Available in (Ebobrah et al. 2010: 3).

${ }^{12}$ Articles 17 and 18, 19 and 16 of the Convention Governing the Court of Justice of the CEMAC (July 5, 1996) available at http://www.aictctia.org/courts_subreg/cemac/cemac_docs.html

${ }^{13}$ Articles 33 and 34, and 29 of the Treaty for the Establishment of the East African Community (Chapter 8) available in (Ebobrah et al. 2010: 37)

${ }_{14}^{14}$ Article XIV and Article XXIV of the Agreement Establishing the Caribbean Court of Justice (http://www.caribbeancourtofjustice.org/court_instruments.html).

${ }^{15}$ Article 9 and 10 of the Supplementary Protocol Amending the Protocol of the Relating to the Community Court of Justice and Article 77 of the Revised Treaty

for the Establishment of the Economic Community of West African States. Available in (Ebobrah et al. 2010: 194-201)

${ }^{16}$ Article 16, 15 and 18 respectively of the Declaration and Treaty Establishing the Southern African Development Community, Protocol on Tribunal and Rules

of Procedure thereof (2000/2001). Available in: (Ebobrah et al. 2010: 339 and 383). 


\section{Litigation Patterns Across European Style International Courts}

The ECJ emulations are not just paper entities. Together they have issued over 2100 binding legal rulings. Graphs $2 \& 3$ below focuses the first twenty years of judicial activity of the international economic courts for which I could find data, dividing courts based on whether they are European style systems that allow national courts to dialogue with supranational courts and non-state actors to initiate litigation or WTO style inter-state dispute resolution bodies. ${ }^{17}$ To capture the reality that building legal authority takes time, I compare ICs by age, taking the first year that the court issued a ruling as the first year of effective operation and counting years of operation from there (the legend indicates when the IC was formally created and when it issued its first ruling). Litigation rates end based on the age of the system; for example the OHADA system created in 1998 generates only twelve years of data. I combine data for the similarly designed North American Free Trade Area and the US/Canada Free Trade Area but include the GATT system and the WTO system as separate entries; the GATT system lacked compulsory jurisdiction whereas the WTO system (1994-present) has compulsory jurisdiction (and more rules to be applied, and more member states).

\footnotetext{
${ }^{17}$ The counting is conservative; I exclude staff disputes and omit interim rulings. GATT/WTO includes panel rulings; ASEAN is yet to resolve any disputes; Mercosur data includes only rulings of the permanent court (there are also 10 binding ad hoc rulings, but I cannot tell what year these rulings were issued.)
} 


\section{Graphs 2\&3: Litigation Rates by IC Age (1 =first year court issued a ruling)}
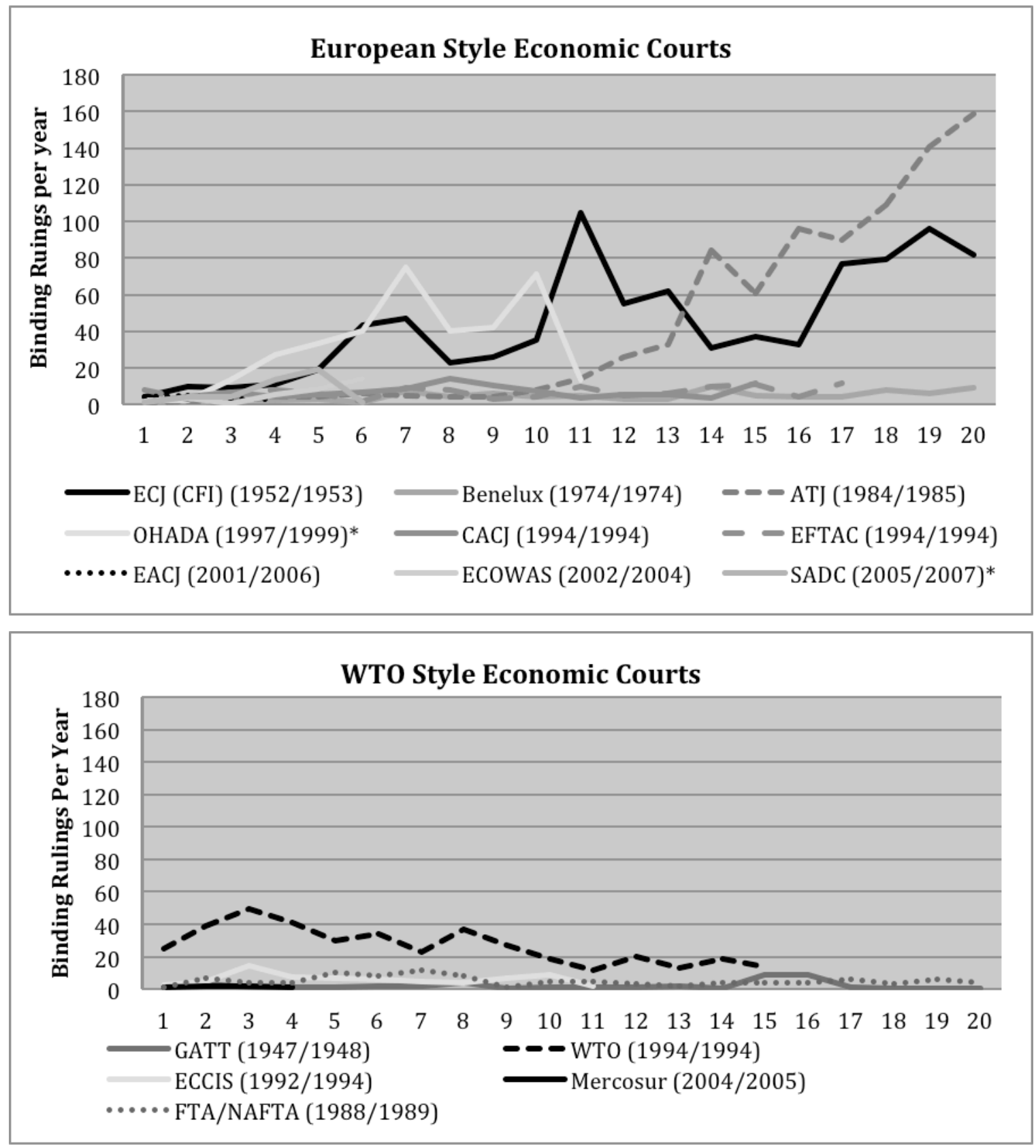

*Reporting of and then actual litigation rates for OHADA declined due to unrest in the Ivory Coast, where the court is located. As of 2010, there are no new appointments and the SADC Tribunal may not accept new cases.

These comparisons are crude; they do not take into account numbers of member states in each system or the extent of member state trade. Still, they are revealing. The graphs show that more active ECJ style courts tend to be busier than WTO style courts, with the busiest ECJ style courts being the ATJ, Benelux, OHADA and EFTAC, which oversee fairly detailed secondary 
legislation. They show that many ECJ and WTO style ICs are clustered at the bottom of the graph. I suspect that copying the ECJ design is neither necessary nor sufficient for an IC to be active because the extent of secondary legislation may be more important in shaping both trade and litigation rates. I lack space to consider an equally important question; whether or not European-style courts emulate the ECJ's penchant for building law that furthers economic and legal integration. I have considered this issue with respect to the ATJ elsewhere (Alter et al. 2010 ; Alter et al. 2011b).

\section{Explaining Emulation: Two Case Studies}

It is easy to see a revealed preference to emulate the ECJ. Explaining this preference is harder. We can see that common market systems tend to emulate the ECJ, whereas free trade systems tend to copy the WTO model. One can thus surmise that the ECJ model is a better fit for common market systems where states intend to create secondary implementing legislation that domestic actors will be applying. But not all regional common market systems create a supranational court. ${ }^{18}$

One can fairly easily eliminate some of Borzel and Risse's potential explanations (in this volume). There is no evidence of coercion influencing the adoption of European style ICs. The EU supports initiatives related to regional legal systems in Africa and Latin America, ${ }^{19}$ but I have found no evidence that the EU uses support to pressure regions to copy their model. Socialization also does not explain the diffusion of European-style ICs. The ECJ is clearly seen as a successful supranational court that has furthered regional integration through its many rulings. Lawyers and judges in regional systems regularly look to the ECJ and its doctrines as a guide; indeed one can easily find citations to ECJ rulings in the legal rulings of European-style ICs. But the ECJ's doctrines are in no way considered legally authoritative outside of Europe. Blind mimicry also does not explain ECJ emulation. As Table 2 revealed, most ECJ copies have adapted the ECJ model.

The best I can say by way of explanation is that the European model appears to supporters as a way to promote law compliance and perhaps spur integration through law. Pro-

\footnotetext{
${ }^{18}$ The Central American Common Market proposed creating an ECJ style court around the same time as the Andean Community but did not follow the recommendation (Saldias 2010: 12); the African Union, ECCIS and Mercosur have indicated a desire to build a common market, and there are existing recommendations for ECJ style ICs.

${ }^{19}$ For example, the EU provides in-kind consultants, sponsors conferences and exchanges among judges, subsidizes projects to support fledgling regional legal systems such as web pages and outreach for regional ICs.
} 
integration advocates tend to lobby for ECJ style courts, making it fairly easy to find official and unofficial proposals for ECJ style ICs in many if not most regional systems. These proposals, which are often proffered by people inspired by the European model, can languish for years. My studies of the Andean and ECOWAS systems suggest that governments may be more easily convinced to create formally binding oversight mechanisms when they want to signal a heightened commitment to market integration. As was true in Europe, governments also seem convinced that they can avoid or ignore supranational litigation.

The rest of this paper explores two cases. The OHADA and ECOWAS systems, both European-style ICs influenced by European IC models, do not directly copy the ECJ design. In OHADA, the French government actively promoted creating a modified European-style IC. In ECOWAS, actors were clearly drawing lessons from Europe and other ECJ copies, but the EU had no influence over the outcome. I selected these two cases because while both systems are young, they appear to be successfully mobilizing support constituencies to bring cases, disseminate rulings and promote compliance. Another successful European-style IC is Andean Tribunal of Justice (ATJ). Elsewhere I show how the EU model exerted a more direct influence over the initial design and jurisprudence of the ATJ, with the mode of diffusion being 'lesson drawing' as in the cases discussed below (See Alter et al. 2011c). Like the ECOWAS court, when states wanted a more effective IC they adopted changes that brought the existing IC closer in design to the ECJ model (See Alter et al. 2011c).

\section{The Organization for the Harmonization of Business Laws in Africa (OHADA)}

The Organization for the Harmonization of Business Law in Africa (OHADA), formed in 1993, creates unified business codes for African countries. Its members are predominately francophone African countries, all of which had anachronistic business rules left over from French colonialism and adapted in a hodgepodge fashion so that few lawyers or judges even knew what governing law applied. The result, everyone seemed to agree, was legal uncertainty that was worrisome to potential investors (Mouloul 2009: 10-11).

The impetus to create OHADA came both internally and externally. Foreign investment in the region fell in the 1980s due to political instability and the reorientation of financial supports in the post-Cold War era. Political leaders wanted more foreign investment, and they became convinced that legal and juridical insecurity made investing in their markets less 
desirable. Adopting a common commercial code offered many advantages. By having the same set of rules across countries, foreign investors could save on the legal expertise needed for each national system. OHADA Uniform Acts were also adapted specifically for the needs of developing countries, so that they became more attractive than competing rules-existing French, American or EU business law (Dickerson 2005: 25-30; Mouloul 2009). Member states may not amend the Uniform Acts, and the Acts are widely available on the internet and in source books, providing legal stability and certainty. The promulgation of eight multilaterally crafted Uniform Acts between 1998 and 2004 activated the OHADA system. OHADA's Uniform Acts are detailed, ranging from thirty-one to 920 articles in length and addressing a broad range of issues such as commercial law, securities, recovery procedures, bankruptcy and accounting systems. OHADA's legal system was also one of OHADA's chief attractions. Foreign lawyers have little faith in Africa's national legal systems, where judges are perceived to be ill informed and often corrupt. International dispute resolution is an alternative, but it is expensive because cases are litigated outside of the region. ${ }^{20}$ OHADA created its own arbitration system that is managed by the Common Court of Justice and Arbitration (CCJA) and it provides an international review of national judicial rulings.

Externally the OHADA system was strongly supported by the French government, with the encouragement of the Conseil Francais des Investisseurs en Afrique (CIAN). The French government was interested in any solution that might help to stabilize the Franc zone, because regional instability could generate currency pressures felt in France. A 1991 meeting of African finance ministers from African Franc countries, held in France, led to the commissioning of a study on the feasibility of creating regional business law (Tiger 2001: 23-4). The French Foreign Ministry reached out to Kéba Mbaye, a former Senegalese Supreme Court judge and President of the International Court of Justice, who in the 1960s had advocated legal harmonization among newly independent states. The French Foreign Ministry underwrote and provided technical support for Mbaye's efforts, which led to the founding of OHADA (Katendi et al. ). France, other EU and non-EU countries, and other international institutions provided financial support to pay for OHADA (Mouloul 2009). While member states now also provide support for the system, it is safe to say that foreign support has been instrumental to the functioning of OHADA. Also, the French Foreign Ministry to this day has at least one attaché at the OHADA secretariat.

\footnotetext{
${ }^{20}$ Interviews with two French business lawyers to work with OHADA law. 24 March 2010, Paris France.
} 
When it appeared that the soon-to-be-implemented OHADA Uniform Acts had been largely forgotten, French patrons, with the support of funding from various international institutions, created a non-governmental organization to promote awareness of OHADA and its laws. The Association for the Unification of African Law (UNIDA) plays an analogous role to Eurolaw associations, which formed in the 1950s and 1960s to help promote European Community law (Alter 2009: Chapter 4). UNIDA helps with training sessions and maintains a website-OHADA.com--that makes available OHADA Uniform Acts, and CCJA and national court rulings applying OHADA law. The French journal Juriscope, with the support of Coopération Français, publish commentary and compendiums of Uniform Acts and community case law, which they help to distribute throughout the region. This is important because in many African countries journals publishing laws and legal rulings are irregularly maintained and hard to access. Members of UNIDA's network regularly visit national courts to collect rulings that pertain to OHADA. The rulings are transcribed and published on line. ${ }^{21}$ While the collection of national legal rulings on OHADA.com is surely incomplete, UNIDA's website supplies what may be the only publicly available searchable source for case law in OHADA member states.

The combination of the Uniform Acts and international review of national court rulings makes the OHADA system a "European style" IC. Why not create, however, a supranational court modelled on the ECJ? One reason perhaps is that OHADA is intentionally different from a common market. If OHADA had a larger political objective, like establishing a monetary union or good governance norms, it would be in direct competition with the West and Central African Economic and Monetary Unions, which promote economic integration among former French colonies. $^{22}$ Moreover, OHADA aspires to provide a set of business laws that any country can adopt. OHADA is also primarily designed for business contracts, thus it does not need to replicate the inter-state dispute resolution mechanisms of the WTO or the supranational enforcement mechanism of the EU. The 2008 Quebec reforms have brought OHADA institutions closer in form to the EU, ${ }^{23}$ but the format for creating Uniform Acts in OHADA remains

\footnotetext{
${ }^{21}$ Interviews with a UNIDA staff member coordinating the collection and publication of national court rulings. 22 March 2010 Paris.

${ }^{22}$ Benin, Burkina Faso, Ivory Coast, Guinea, Mali, Niger, Nigeria and Senegal are members of both OHADA, the West African Economic and Monetary Community and the Economic Community of West African States. Cameroon, Central African Republic, Republic of Congo, Equatorial Guinea and Gabon are members of both OHADA and the Central African Monetary Community.

${ }^{23}$ The reforms created a Council of Ministers that can adopt and amend Uniform Acts and oversee the operation of the OHADA Secretariat and Court. The Permanent Secretariat manages the legal affairs and accounting, and it works with
} 
multilateral more than supranational. There is thus no reason to create administrative and constitutional review roles as checks on supranational authority.

The existence of detailed primary OHADA law explains why the OHADA system is more active than other African regional legal systems. But while OHADA law is formally speaking the supreme business law of the land, and CCJA decisions the highest legal authority on the meaning of OHADA law, much of the economies of member states remains informal and thus outside of the sphere of OHADA law (Dickerson 2007). Within the sphere of business adjudication, litigants may choose arbitration, and sometimes litigants choose to remain in the national system instead of appealing to the CCJA. Also hindering OHADA is that national supreme courts remain wary about working with the CCJA (Dickerson 2005: 57), and many national judges are ignorant of the workings of OHADA. For all of these reasons there is a real question how much of Africa's business affairs are truly governed by OHADA rules.

\section{The Economic Community of West African States (ECOWAS)}

The original treaty for the Economic Community of West African States, adopted in 1975, included a provision that allowed for the establishment of a Community Court. An 'Eminent Persons Group' drafted the initial Protocol Relating To The Community Court Of Justice in 1991 (A/P.1/7/91). I do not know if they considered the ECJ model, but clearly West African leaders did not want a court that private actors could seize to challenge the many tariffs, regulations and border closings that governments regularly enact to protect their national economies. The Protocol, ratified in 1995 and formally entering into force in 1996, did not really copy the ECJ model. States could bring noncompliance suits on behalf of their citizens, but the original ECOWAS court did not allow national court references and the Secretariat had no role in monitoring or helping to enforce community rules. Ratifying the protocol did not lead to the creation of a Community Court; judges were appointed only in 2002. When ECOWAS officials finally constituted the ECOWAS Court, member states made what in retrospect was a portentous decision; in their expectation of a major relauching of regional integration, they decided to make the new court a permanent body. ${ }^{24}$

The ECOWAS Community Court of Justice (ECCJ) sat largely unused because states

\footnotetext{
the Council of Ministers to propose new areas of business law harmonization and to draft new laws.
}

${ }^{24}$ Based on interviews at the ECOWAS Secretariat, 7 March 2011, Abuja Nigeria. 
never brought cases. The ECOWAS Secretariat quickly grew frustrated that judges consumed significant community expenses without actually contributing to the goals of the community. The problem was the Court's extremely limited rules of access. One obvious problem is that states would not bring cases against themselves. A second limitation was that few attorney generals knew about the ECOWAS system, and mobilizing them to raise a case on behalf of a private actor is not easy. The first case to finally reach the ECOWAS court was a private litigant challenge to Nigeria's closing of its borders in clear violation of the ECOWAS treaty. The private plaintiff asked the ECCJ to engage in lawmaking by purposively interpreting its mandate to overcome the 'absurdity' that expects a state to be both a plaintiff and a defendant in suits. The ECCJ refused the invitation, sticking to the plain wording of its mandate that only allowed 'disputes instituted by member states on behalf of its nationals against another Member State. ${ }^{25}$

The ECCJ then used the ruling to lobby for an expansion of its jurisdiction. The ECCJ printed and disseminated copies of its unsatisfactory ruling, and in 2004 the judges drafted a proposal to expand the ECCJ's jurisdiction. The judges asked for changes that would bring the ECCJ closer in design to the ECJ model, including adding a preliminary ruling mechanism similar to that of the West African Economic and Monetary Union (WAEMU). ${ }^{26}$ Instead, they got something different. After the Court's initial request, the future role of the Community Court of Justice became a topic of discussion at a conference sponsored by the Open Society Justice Initiative. Participants at the conference, which included human rights lawyers, representatives of the West African Bar association, and ECOWAS officials (Nwogu 2007: 352), tasked the ECOWAS legal secretariat with drafting a supplementary protocol. The 2005 Supplementary protocol allows national courts to refer cases to the community court but it does not copy the WAEMU provision, which requires national courts of last instance to refer cases to the community court. It also allows authorizes what is now the Commission to initiate noncompliance suits. A surprising outcome is that the ECOWAS court received jurisdiction for private complaints against human rights abuses. Not only can litigants bring a case directly to the court, they do not even have to first exhaust domestic remedies (Ebobrah 2007 ; Alter et al. 2011a).

According to participants, this change of jurisdiction went through with little controversy.

\footnotetext{
${ }^{25} \mathrm{Mr}$. Oleyide Afolabi v. Federal Republic of Nigeria ECW.CCJ.APP.01.03 Decision of 27 April 2004.

${ }^{26}$ The WAEMU system is a more direct copy of the ECJ model, and all WAEMU countries are also part of ECOWAS. Based on interviews at the ECOWAS Community Court of Justice, 11 March 2011 Abuja Nigeria.
} 
A member of the ECOWAS legal secretariat told us that member states "did not give much thought to what the changes to the Court's jurisdiction and access might mean for them." The change was also only provisional, a sort of 'trial and error' decision that states expected they could revisit. ${ }^{27}$ Two things happened to make this change permanent. In yet another drive to improve the functioning of the ECOWAS system, member states agreed to a series of institutional changes that emulate the EU including transforming the Executive Secretariat into a Commission that also helps to monitor compliance with community rules, agreeing to govern through greater supranationality, and making Supplementary Acts a mode of amending the founding Treaty. The 'provisional' Supplementary Acts thus became permanent a permanent amendment. Second, when the Gambian government proposed adjustments to the Community Court's jurisdiction, the rejection of the proposals served as a political ratification of the status quo. The Gambian proposals were actually fairly reasonable; they included requiring litigants to exhaust domestic remedies and allowing the ECCJ to only apply human rights agreements that member states had ratified. ${ }^{28}$ Both of these proposals were rejected because the Attorney Generals of ECOWAS member states knew the proposals were in response to ECCJ decisions finding Gambia guilty of detaining and torturing political opponents. ${ }^{29}$ While the ECCJ's jurisdiction may yet be adjusted should the court become overrun with suits, the key stakeholders we interviewed consider the Supplementary Protocol to be firmly entrenched in the ECOWAS system.

In ECOWAS, the ECJ model influenced modifications of the ECCJ. But human rights activists trumped economic functionalism in shaping the course of institutional development. The counter-intuitive outcome is that private actors can only challenge patently illegal economic policies, like closing borders or requiring individuals to deposit $\$ 300,000$ to open a business, if such policies give rise to human rights abuses.

\footnotetext{
${ }^{27}$ Interview at the legal secretariat of the ECOWAS Commission, 7 March 2011, Abuja Nigeria.

${ }^{28}$ See "ECOWAS Court and the Promise of the Local Remedies Rule" a Human Rights Brief by the Center for Human Rights and Humanitarian law. http://hrbrief.org/2009/11/ecowas-court-and-the-promise-of-the-localremedies-rule/ last accessed 14 June 2011.

${ }^{29}$ Chief Ebrimah Manneh vs Republic of Gambia ECW/CO/ APP/04/07 Decision of 05/06/2008; Musa Saidykhan vs. Republic of Gambia ECW/CO/APP/L1/07 decision of 16 December 2010. The proposals were leaked to human rights activists, who were then given access to the meeting where they were discussed. The human rights reinforcements made it even harder for Government officials to side with the representative of the Gambian Attorney General. Based on interviews with human rights advocates from the Open Society Justice Initiative (11 January 2011, and 3 February 2011, both by phone). This perspective was corroborated in interviews at the ECOWAS legal secretariat, 7 March 2011, Abuja Nigeria.
} 


\section{Conclusion: Diffusing the European Approach to International Law}

The ECJ-model has clearly diffused around the world. The best explanation for this fact is that regions are drawing lessons from the ECJ's experience. What, however, are regional systems learning? In the 1960s, many regions copied Europe's approach to regional integration, without creating supranational courts. Most of these regional economic systems remained lackluster, failing to achieve their primary economic and political objectives (Mattli 1999). Legal observers noticed that the ECJ was helpful in overcoming legal difficulties arising in the process of regional integration, and they frequently proposed creating ECJ style ICs. These proposals languished until member states sought to relaunch regional economic integration endeavors. Adopting provisions to establish a community court became part of a package of reforms aimed at making regional integration systems more robust.

Supranational legal architects also learned from the ECJ's experience. Some regional integration projects wrote safeguards to protect national sovereignty into their Court's founding charters, such as not requiring national court references or limiting the content of the Court's reply. But they also explicitly incorporated the ECJ's revolutionary doctrines of the direct effect and supremacy of community law, and the idea that "community law" is distinct from traditional international law. Judges and lawyers working in regional ICs also learn from ECJ's jurisprudence, although they use this jurisprudence as a guide rather than as dogma.

Many local factors hinder regional ICs from following the ECJ's trajectory. Most regional ICs remain hampered by a lack secondary legislation that might spur litigants to invoke community law and judges and administrators to work with Community institutions. Also challenging is that ECJ emulators are located in the developing world, where national judges are weak, reluctant and at times corrupt partners. The limited political and judicial support means that ECJ copies resemble more closely in practice the ECJ during the 1950s and 1960s than the ECJ of today.

While I have documented the emulation of the ECJ, I argued that one should not focus too much on institutional copying. Europe has contributed in many ways to the expansion of the global judiciary, by offering models of human rights, war crimes and economic courts that others could emulate, and by being a constant force facilitating the creation and development of international legal mechanisms (Alter 2011). The European Union does not need to pressure or coerce others to follow its lead; the ECJ model has its own attractions and adherents. The 
existence of ECJ copies allows us to hold constant the design of the IC, to explore how ICs build their authority. We can take variation in litigation rates as a sign of varying demand for IC rulings, which itself reflects limited social and political mobilization around community goals.

Wade Jacoby argued that institutions diffuse through a combination of external pressures and internal mobilization. A coalitional approach to building domestic institutions based on foreign models, he argues, tends to result in more robust domestic institutions compared to emulations that are imposed or simply put in to substitute for what existed before (Jacoby 2006). I have explored in greater depth European-style ICs where litigation rates are growing. Jacoby's argument appears to hold. Faithfully copying the ECJ is not as likely to ensure institutional success than is building an international legal system that local actors find useful. Promoting regional free trade is not necessarily locally useful, which may be why regional integration systems lack secondary legislation and remain politically marginal. The OHADA system aims to attract foreign investment, and the ECOWAS system increasingly focuses on promoting good governance practices in the region. Both of these objectives are politically popular. The dependence of international courts on national interlocutors means that ECJ copies may not become lawmaking engines of market liberalization. This does not mean, however, that one should count these ICs out. We may find that they instead become promoters of good governance, and dispute resolution bodies for foreign actors that that see litigation as a useful means to promote their objectives.

\section{Bibliography}

Alter, Karen, and Laurence Helfer (2010). "Nature or Nurture: Judicial Lawmaking in the European Court of Justice and the Andean Tribunal of Justice", International Organization, 64:4, 563-92.

Alter, Karen J. (2009). The European Court's Political Power: Selected Essays, Oxford: Oxford University Press.

Alter, Karen J. (2011). "The Evolving Transnational Legal Order", Annual Review of Law and Social Science, 7.

Alter, Karen J., Laurence Helfer, and Jacqueline McAllister (2011a). "Building a Human Rights Rule of Law in the Economic Community of West African States", Manuscript in progress.

Alter, Karen J., and Laurence R. Helfer (2011b). "Legal Integration in the Andes: Lawmaking by the Andean Tribunal of Justice", European Law Journal 17:5, 713-27. 
Alter, Karen J., Laurence Helfer, and Osvaldo Saldias (2011c). Transplanting the European Court of Justice: The Founding of the Andean Tribunal of Justice. Onati Working Paper Series.

Bates, Ed (2011). The Evolution of the European Convention on Human Rights, Oxford: Oxford University Press.

Boerger-De Smedt, Anne (2008). "La Court de Justice dans les négociationis du traité de Paris instituant la CECA", Journal of European History, 14:2, 7-34.

Dickerson, Claire Moore (2005). "Harmonizing Business Laws in Africa: OHADA Calls the Tune", Columbia Journal of Transnational Law, 44:17, 18-73.

Dickerson, Claire Moore (2007). "The Cameroonian Experience under OHADA: Business Organizations in a Developing Economy", Business and Society Review, 112:2, 191-213.

Ebobrah, Solomon (2007). "A rights-protection goldmine or a waiting volcanic eruption? Competence of, and access to, the human rights jurisdiction of the ECOWAS Community Court of Justice", African Human Rights Journal, 7, 307-329.

Ebobrah, Solomon, and Armand Tanoh (2010). Compendium of African Sub-Regional Human Rights Documents, Pretoria: Pretoria University Law Press.

Gillingham, John (1991). Coal, steel, and the rebirth of Europe, 1945-1955 : the Germans and French from Ruhr conflict to Economic Community, Cambridge [England] ; New York, NY, USA: Cambridge University Press.

Hanson, Brian (1998). "What Happened to Fortress Europe?: External Trade Policy Liberalization in the European Union", International Organization, 52:1, 32.

Hathaway, Oona (2005). "Between Power and Principle: A Political Theory of International Law", University of Chicago Law Review, 71:2, 469-536.

Helfer, Laurence, and Anne-Marie Slaughter (1997). "Toward a Theory of Effective Supranational Adjudication", Yale Law Journal, 107:2, 273-391.

Hudec, Robert E. (1993). Enforcing International Trade Law: Evolution of the Modern GATT System, New Hampshire: Butterworths.

Jacoby, Wade (2006). "Inspiration, Coalition and Substitution: External Influences on PostCommunist Transformations", World Politics, 58:4, 623-651.

Katendi, Francois, and Jean-Baptiste Placca Savoir accepter la pauvreté : Interview de Kéba MBAYE. l'autre Afrique. OHADA.COM.

Levi, Werner (1976). Law and Politics in the International Society, Beverly Hills: Sage Publications.

Madsen, Mikael Rask, and Antoine Vauchez (2005). "European Constitutionalism at the Cradle. Law and Lawyers in the Construction of a European Political Order (19201960)", in Alex Jettinghoff and Harm Schepel (eds.), In Lawyers' Circles. Lawyers and European Legal Integration. The Hague: Elzevir Reed, 15-34.

Mattli, Walter (1999). The Logic of Regional Integration, Cambridge: Cambridge University Press. 
Mouloul, Alhousseini (2009). Understanding the Organization for the Harmonization of Business Laws in Africa (O.H.A.D.A.). Paris.

Nwogu, Nneoma (2007). "Regional Integration as an Instrument of Human Rights: Reconceptualizing ECOWAS", Journal of Human Rights, 6, 345-36.

Nyman Metcalf, Katrin, and Ioannis Papageorgiou (2005). Regional Integration and Courts of Justice, Antwerp: Intersentia.

Pescatore, Pierre (1981). "Les Travaux du $<<$ Groupe Juridique $>>$ Dans la négociation des Traités de Rome", Studia Diplomatica (Chronique de Politique Etrangère), XXXIV:1-4, 159-178.

Robertson, A.H., and J. G. Merrills (1994). Human Rights in Europe, Manchester: Manchester University Press.

Saldias, Osvaldo (2010). "Networks, Courts and Regional Integration: Explaining the Establishment of the Andean Court of Justice", Working Paper of the KFG The Transformative Power of Europe, No. 20 November 2010.

Scheingold, Stuart (1965). The Rule of Law in European Integration, New Haven: Yale University Press.

Schermers, Henry G. (1999). "Acceptance of International Supervision of Human Rights", Leiden Journal of International Law, 12, 821-831.

Stein, Eric (1981). "Lawyers, Judges and the Making of a Transnational Constitution", American Journal of International Law, 75:1, 1-27.

Stone Sweet, Alec (2004). The Judicial Construction of Europe, Oxford: Oxford University Press.

Tiger, Philippe (2001). Le droit des affaires en Afrique, Paris: Press Universitaires de France.

Watson, Alan (1993). Legal Transplants: An Approach to Comparative Law, Athens Georgia: The University of Georgia Press.

Weiler, Joseph (1991). "The Transformation of Europe", Yale Law Journal, 100, 2403-2483. 